\title{
'In New Zealand I feel more confidence': The role of context in the willingness to communicate (WTC) of migrant Iranian English language learners
}

\author{
DENISE CAMERON* \\ Auckland University of Technology
}

Received: 22/07/2014. Accepted: 13/03/2015.

\begin{abstract}
This article will discuss recent theories of Willingness to Communicate (WTC) and provide an overview of studies into this individual difference which have been conducted in both Iran and New Zealand (NZ). So far few qualitative studies have been carried out into WTC or have used permanent migrants as participants. The article reports on a longitudinal study of the WTC of a group of Iranian migrants to NZ. By means of questionnaires, observations, and individual semi-structured interviews conducted at six-month intervals, case studies of these learners in a NZ university English class were compiled. Their WTC was found to encompass such learner characteristics as confidence, motivation, and personality, and varied from country to country and semester to semester. Finally, this article discusses the contribution of this study to the WTC field of research, identifying the implications of these results for teachers of English in the ESL (English as a Second language/migrant) context and possible avenues for future research.
\end{abstract}

KEYWORDS: Willingness to communicate, context, anxiety, personality, motivation, case study.

\section{RESUMEN}

Este artículo examina teorías recientes sobre la Disposición a Comunicarse (Willingness to Communicate, WTC) y proporciona una visión general de estudios realizados en Irán y Nueva Zelanda acerca de esta diferencia individual. Hasta la fecha hemos tenido pocos estudios cualitativos realizados sobre la WTC o se han utilizado emigrantes permanentes como participantes. El artículo informa sobre un estudio longitudinal de la WTC de un grupo de emigrantes iraníes en Nueva Zelanda. Los resultados indican que la WTC estaba relacionada con características del aprendiz tales como seguridad en sí mismo, motivación y personalidad, y que variaba de país a país y de semestre a semestre. Al final, el artículo analiza la contribución de este estudio a la investigación en el campo de la WTC e identifica las implicaciones de estos resultados para los profesores en el contexto de ESL (Inglés como Segunda Lengua/emigrantes) además de posibilidades de investigación para el futuro.

PALABRAS CLAVE: Disposición a comunicarse, contexto, ansiedad, personalidad, motivación, estudio de casos prácticos.

*Address for correspondence: Denise Cameron. School of Language \& Culture, Auckland University of Technology, Pvte Bag 92006, Auckland, New Zealand 1142; e-mail: denise.cameron@aut.ac.nz 


\section{INTRODUCTION}

Dörnyei (2010: 252) has dismissed as an "idealized myth" the idea that individual differences (IDs) in learners are stable and monolithic traits. Instead they display "a considerable amount of variation from time to time and from situation to situation" (ibid: 252). Willingness to communicate (WTC) in the L2 has been regarded as one of these variables since its initial conception more than a decade ago.

Willingness to communicate was originally conceived in the L1 as "an individual's predisposition to initiate communication with others" (McCroskey, 1997: 77). Extending this to the second language situation, MacIntyre et al. (1998: 547) defined WTC "as a readiness to enter into discourse at a particular time with a specific person or persons, using a L2."

Kang (2005), however, as a result of her study of Korean Study Abroad (SA) students proposed another definition of WTC as a situational variable: "Willingness to communicate is an individual's volitional inclination toward actively engaging in the act of communication in a specific situation, which can vary according to interlocutor(s), topic, and conversational context, among other potential situational variables" (p. 291).

Whether Willingness to Communicate is a permanent trait or is modified by situational context has previously been investigated in various studies (e.g., Cao \& Philp, 2006; Kang, 2005). More recently the importance of Dynamic Systems Theory to WTC has been revealed (MacIntyre \& Legatto, 2011), as well as Action Control Theory (MacIntyre \& Doucette, 2010). However, most of this research has been quantitative and conducted in the English as a Foreign Language or Study Abroad situation in countries such as Canada, Japan, Korea and China. Middle Eastern students have only recently begun to be the focus of WTC studies published in English (e.g., Çetinkaya, 2005; Ghonsooly et al., 2012; Zarrinabadi, 2014).

The nature of the WTC of permanent migrants to an English-speaking country also remains an under-reported area of research (except for Zhong, 2013). If the context of the migrants' English learning is radically changed, then perhaps their motivation and other personal factors which contribute to their WTC could be affected either positively or negatively.

Therefore, this study was designed to investigate how the particular variable of "change of language learning context" affected the WTC of Iranian migrants to New Zealand (NZ). The study was conducted over two semesters (one year) with four pre-university ESL (English as a Second Language) students who were interviewed by the researcher after completing a written questionnaire. Building on the results of a previous exploratory study (Cameron, 2013), an observation tool was used as well as the longitudinal dimension, in order to enhance the validity of the findings of this qualitative study. Before discussing these findings, the literature which forms the background to this study will be presented in the following section. 


\section{LITERATURE REVIEW}

SLA researchers in the last decade have emphasized the importance of WTC in the L2 as a vital component of modern language instruction (e.g., de St Léger \& Storch, 2009; MacIntyre \& Legatto, 2011; MacIntyre et al., 1998). Communicative competence alone may not result in actual L2 communication in or outside the classroom. However, "L2 learners with a high level of WTC are more likely to use L2 in authentic communication and facilitate language learning" (Kang, 2005: 278). In fact, there is a great variety of communicative competence levels among L2 users. This has been attributed to social factors associated with L2 use (MacIntyre et al., 1998); as well as differences in types of classroom (Baker \& MacIntyre, 2000); or interactional context in which the L2 WTC is exhibited, i.e. whole class, small group, or pair interaction (Cao \& Philp, 2006).

\subsection{Dynamic systems theory and WTC}

More recently, a variety of psychological and behavioural theories have been applied to describe or explain WTC more comprehensively. Dynamic Systems Theory has been recommended by researchers and theorists as being particularly appropriate for investigating WTC and other individual differences (e.g., Dörnyei, 2009, 2010; MacIntyre, 2007; Yashima, 2012). Four key properties have been identified by de Bot et al. (2007) as belonging to these systems. First is the fact that dynamic systems change over time so each state is a transformation of a previous one. Second, these systems are completely interconnected so they are able to influence each other. Third, they are self-organizing into preferred or attractor states, and states that will not be preferred (repeller states), so change is to be expected as variables which affect the system change over time. The fourth has been termed the butterfly effect, as small changes in one part of the system may have large effects overall, but equally, large disturbances may only produce small effects in the whole system.

Aspects of WTC have been considered "dynamic" and situational since the creation of MacIntyre et al.'s (1998) original construct, but only recently has WTC been viewed as a "dynamic system" in itself. MacIntyre and Legatto (2011) have suggested that WTC shows the properties of a dynamic system as there are changes over time wherein each state is partially dependent on the previous. A learner's WTC is likely to be affected by their WTC on a previous occasion in another context, whether immediately before or at some stage in the past. There is also an interconnectedness between the linguistic, social, cognitive, and emotional systems which produce WTC. When these systems function well together, WTC can be seen as an attractor state, whereas interference, such as when there is a deficiency in language or the affective state of the speaker is compromised, can cause a repeller state and communication is abandoned. 


\subsection{Action control theory and WTC}

In addition, Kuhl's (1994) theory of action control, which has as its basis hesitation, preoccupation, and volatility, has been proposed by MacIntyre and Doucette (2010) as a precursor for WTC. In their view, hesitation involves the inability to translate decisions into actions such as communicating in the L2. Preoccupation measures the extent to which intrusive and enduring thoughts cause a person to fail to initiate behaviour. In this case, learners may fail to initiate communication when they remember past failures or unpleasant classroom experiences. Thus hesitation and preoccupation will be associated with higher language anxiety and lower perceived competence. Volatility represents an inability to stay focussed on a task (as opposed to persistence). MacIntyre and Doucette suggest that although the components of action control are enduring and trait-like, their effects in situ may be influenced by situational variables.

\subsection{Individual differences and WTC}

The study of language learner characteristics or individual differences, both trait and situational, has been a tradition in second language studies since the 1970s. However, in 1994, MacIntyre and Noels predicted that research into the effects of single variables would be replaced by future studies which would provide a more comprehensive model of language learning. Perhaps as a result of this in 1998, MacIntyre, Dörnyei, Clément, and Noels collaborated in the creation of a heuristic model which related specifically to the combination of variables which contribute to WTC. This "Pyramid Model" of WTC was the first structural representation of the components of L2 WTC, divided into both situational and stable features or individual differences (IDs). It integrated psychological, linguistic, educational, and communicative dimensions previously studied independently in order to predict a willingness to converse in the L2. The elements of this pyramid, whether individually or in various combinations, remained the foci for empirical WTC research over the next decade, as researchers endeavoured to identify a range of affective/individual and social contextual variables which contributed to WTC.

\subsection{Context and WTC}

Context in relation to $\mathrm{L} 2$ acquisition can be described along a variety of dimensions ranging from a specific language to the society in which it is spoken (MacIntyre et al., 2007). Moreover, Ushioda (2009) has described learners as "persons-in-context" in a constantly evolving interaction with their environment and advises that they need to be understood holistically as people in a particular context or contexts. Such an investigation requires the 
exploration of individual factors but not in an isolated way (Ushioda, 2014). Learner characteristics and contextual characteristics are inevitably intertwined but a pragmatic approach means that only certain features can be explored at any one time. In this study it is the constituents of WTC of the participants in the pedagogical context of the classroom within the societal context of Iran and NZ which are being examined.

In her study of WTC, Cao (2011) stressed the notion of context (both micro and macro, i.e. inside and outside the classroom) in language learning as a central and focal theme, which is socially constructed and dynamically negotiated on a moment-to-moment basis. Moreover, Clément et al. (2007), in their theoretical discussion of the place of context in WTC research, maintain that WTC increases the likelihood that one speaks more frequently. Therefore, WTC is "relevant to setting the interpersonal social context in which L2 interactions take place" (p. 62). They also state that: "The understanding of contextual effects lies with an adequate understanding of the transactions between individuals embedded in specific cultural contexts" (ibid: : 70).

Such cultural contexts have been investigated by researchers in China (Peng, 2007, 2012; Peng \& Woodrow, 2010) and also Japan (Yashima, 2002; Yashima \& Zenuk-Nishide, 2008). However, the variety of learning contexts in which WTC has been researched so far is quite limited. The French immersion situation in Canada, the EFL context in a number of Asian and a few Middle Eastern countries, and the experiences of Study Abroad students constitute the range of published studies up to this point in time. The extension of WTC studies to Iranian learners widens the range of cultural contexts in which this construct has been applied. Although studies of the WTC of Iranians in Iran have taken place (e.g., Ghonsooly et al., 2012), no reports have been published so far specifically targeting this group in other countries. As a result of past political events in Iran leading to migration, and an increasing number of Iranian Study Abroad students in overseas universities, this nationality group makes up a significant component of many English language classes.

The different effects of an ESL context, that is migrants learning English in a country where they have permanently settled, on students' WTC are yet to be fully explored, although one NZ study has recently been published which begins to address this area of research. Zhong (2013) found that the WTC and oral communication of her Chinese migrant learners varied in different situations in the L2 classroom, supporting the argument that WTC is context-dependent and situational. A mixture of linguistic, affective, and socio-cultural factors contributed to their reticence to participate in a teacher-fronted situation and their greater WTC in collaborative learning situations. No other published studies to this date have asked their participants about their WTC in their previous English learning situation or context.

Therefore, the overarching question being addressed in this study was: "To what extent are the individual factors affecting the WTC of Iranian migrant learners of English in NZ a 
dynamic phenomenon influenced by change in learning context?" As a focus for the study the following research questions (RQs) were framed:

1. Which individual factors do Iranian learners regard as influential in their willingness to communicate in the English language classroom context, both in Iran and NZ?

2. How do Iranian learners perceive any contextual variations in their WTC from an EFL environment in a non-English speaking country (Iran) to an ESL classroom in their new country of migration (NZ)?

3. How do Iranian learners perceive any contextual variations in their WTC over two semesters in two NZ English pre-university classes?

\section{METHODOLOGY}

\subsection{Methodological approach}

A qualitative approach was chosen for this study, both because it filled a gap in the current exploration of WTC, as well as reflecting the complex and dynamic nature of the topic. "Phenomenological inquiry, or qualitative research, uses a naturalistic approach that seeks to understand phenomena in context-specific settings" (Hoepfl, 1997: 1). WTC could be considered to be such a phenomenon of individual lived experience. Until recently investigations into WTC have been strongly influenced by quantitative social psychology, whereas "qualitative studies have not traditionally been part of the research repertoire" (Dörnyei, 2001: 239). Mixed methods research (i.e. a combination of quantitative and qualitative) has been applied to WTC (see Cao \& Philp, 2006; MacIntyre \& Legatto, 2011; Peng, 2012), but published studies using purely qualitative methods are still comparatively rare (see Cao, 2011, 2013; MacIntyre \& Blackie, 2012; MacIntyre, Burns \& Jessome, 2011; Zhong, 2013).

Using methods typical of qualitative research such as interviews, observations, and textual analysis, this study sets out to investigate and describe the WTC behaviour of a small group of learner participants in a holistic way. To this end a multiple case study approach was adopted (see Duff, 2008) and participants selected with some homogeneity, that is their original nationality was Iranian; all had previous English language learning experience in Iran; and all were members of the same English class level. A longitudinal investigation was 
undertaken to provide more than the "snapshot" approach of the purely quantitative practitioner (Yin, 2003).

\subsection{Context and participants}

The research site for the study was a NZ university, although the two consecutive classes which the four participants attended (Advanced and Academic English 2) were pre-university and were at an IELTS level of approximately 5.5. They were full-time learners enrolled for semester periods of 4-5 months. Their classes covered the four skills of speaking, listening, reading and writing but this study focussed on their willingness to communicate in the speaking aspect of their course.

In accordance with the requirements of the university's ethics committee, the participants were informed of the nature and purpose of the research and invited to take part in the project. Their participation was voluntary and their confidentiality assured. The study was not part of their classwork or assessment programme.

Iranian students were selected as they made up a substantial group in the mixed nationality classes at this university and most had had English language learning experiences in Iran before migrating to NZ. The findings of a previous exploratory study (Cameron, 2013) into the WTC of Iranian participants from the same university suggested that this area of research was worthy of further in-depth investigation. Learning context was an important aspect of these participants' language learning experience, and as such led to their overall WTC (Cameron, 2013). Previous studies by Zhong (2013), Cao (2011), and Peng (2012) also support the important contribution of such contextual factors to learners' WTC.

In the present study, the participant group of 3 women and 1 man were all permanent migrants to NZ, which could have influenced their motivation to learn and communicate in English, as a return to their country of origin was unlikely. This article focusses on the findings related to two participants, Farnaz and Shabnam, as they displayed contrasting cases in terms of their self-described personality traits (Farnaz considered herself to be shy, while Shabnam regarded herself as outgoing), their Iranian English language learning experiences (Farnaz's study experience was much more recent than Shabnam's), and their NZ classroom behaviour (according to their teachers and the researcher/observer, Farnaz exhibited less overt WTC than Shabnam). They were both in their first semester of English study. Such "purposive" or "criterion sampling" is supported by writers on qualitative methods (see Creswell, 2013).

Farnaz was a 36-year-old Kurdish Iranian woman from the north of Iran, whose first language was Turkish. She had graduated with a degree in telecommunications from an Iranian university. She studied English at high school, university, and a private institute shortly before leaving Iran to join her refugee husband in NZ. Two years later, she was now 
working in a primary school library while studying English in a NZ university. She was hoping to enrol for an early Childhood Education degree in the future.

Shabnam was a 42-year-old woman from Tehran, the capital of Iran. She was a teacher in Iran and had learnt some English, but 20 years before, at her high school and a private institute. She was the single mother of two children, one of whom was with her in NZ and the other who came to visit her in NZ during the period of the study. She had been accepted as a refugee in NZ three years before. She was working two full time jobs as a cook and a caregiver as well as studying. She wished to re-qualify as a teacher when she was sufficiently fluent in English.

Table 1 summarises the students' names (these are pseudonyms), age, gender, time in NZ and English language learning experience in Iran.

\begin{tabular}{|l|l|l|l|l|}
\hline Name & Age & Gender & Time in NZ & English Learning in Iran \\
\hline Shabnam & 42 & Female & 3 years & 2 years \\
\hline Farnaz & 36 & Female & 2 years & 10 years \\
\hline
\end{tabular}

Table 1. Participants

\subsection{Data collection instruments and procedure}

Data were generated using four different data collection tools. The first source was a questionnaire designed by the researcher, incorporating seven items and using a four-point Likert-type scale. The questions posed by the questionnaire related to the situations in which the students would find themselves contributing orally in English in their ESL classroom. This was an adaptation of Cao and Philp's (2006) questionnaire, but excluded questions they used relating to WTC outside the classroom, as such data could not be supported by observation. This provided a baseline level of WTC for the participants and a means of determining whether their WTC changed from one semester's class to another as it was administered at the end of each semester. It also included some open-ended questions on WTC, which could be compared with the students' observed classroom behavior, their answers to interview questions, and their teachers' views of their WTC. These data provided answers to RQ1, RQ2, and RQ3.

The second source of data was two in-depth semi-structured interviews conducted by the researcher in English with each participant at six-month intervals (i.e. one per semester). English was used as it is the native language of the researcher and the participants were sufficiently confident and competent in using this L2. The questions were also adapted from Cao and Philp (2006), but additional items about the students' previous language learning experience in Iran and their present NZ classes were added. The second time the students were interviewed they were asked to compare their level of WTC in their previous class (Advanced) with that of their present class (Academic English 2). The data were digitally 
recorded and later transcribed verbatim to reflect as closely as possible the interviewee's "voice" (Duff, 2008). These transcriptions were also submitted to the participants for "member checking" (Duff, 2008). Approval was given by them for the use of the transcriptions without any suggested revisions. Therefore, although the quotations used in the following Results and Discussion section contain grammatical errors, the participants felt their intended meaning was not obscured. These data provided answers to RQ1, RQ2, and RQ3.

An observational tool was devised as the third source of data and incorporated the aspects of WTC the students had commented on in the questionnaire. This required the observer/researcher to note how many times within an hour-long oral interaction class the students contributed to class, group, or pair discussion, and the pedagogical context of these WTC actions. Each of the students were observed on two separate occasions in each semester for a period of one hour and detailed field notes were also taken by the observer. The purpose of the observations was to provide another source of comparison between the students', teachers', and researchers' points of view. These data provided answers to RQ3.

In order to provide a fourth dimension to the findings, at the end of each semester the teachers of the students' two classes were also given a written questionnaire to complete, which was similar to that completed by the students and rated the students on their perceived classroom WTC. These data provided answers to RQ3.

Thus the triangulation of methods, data sources, viewpoints, and time increased the credibility of the study (Patton, 1990).

\subsection{Data analysis}

Although the bulk of the data collected in this study was qualitative, there was a small quantitative element incorporated in the questionnaires and observations. The items in the questionnaire relating to the learners' level of WTC in a variety of classroom interaction situations were analysed to determine high and low levels of WTC. The frequency of the learners' contributions to class, pair, and group discussion in the classroom as observed by the researcher was also noted. In this way a comparison between the teachers', the classroom observer's, and the learners' own evaluation of their WTC could be made.

However, the data in the form of written answers to the open ended questions in the questionnaires, observational notes, semi-structured interview recordings and transcriptions were all analysed qualitatively. As the transcriptions of the semi-structured interviews with teachers and learners were completed and examined carefully over the period of one year, emerging themes were identified, known as "open-coding" (Hoepfl, 1997). Some of these could be predicted from the questions asked in the interviews ("pre-existing codes" - e.g., past learning experience) or previous studies ("theory-generated codes" - e.g., personality, motivation), but others arose as the interviews took place (e.g., external factors). The goal 
was to create preliminary categories as a framework for analysis. These categories were modified or replaced as the analysis progressed.

The next stage was to determine how the categories were linked ("axial coding") in order to acquire a new understanding of the phenomenon under examination (i.e. WTC). However, all these stages did not occur in an entirely linear manner, but rather simultaneously and repeatedly in an "iterative" process as categories were revisited and revised and additional data collected (Hoepfl, 1997). The key was to recognise and identify patterns (Yin, 2003).

\section{RESULTS AND DISCUSSION}

In this section the results of the questionnaires, interviews and observations will be discussed in relation to the two students Farnaz and Shabnam, as they displayed contrasting WTC cases in terms of their self-described personality traits, their Iranian English language learning experiences, and their NZ classroom behaviour. Ushioda (2014: 51) regards "contextual and learner-internal elements" as "interconnected and mutually constitutive" in the complex system of L2 learning so both areas will be explored in the discussion below. The findings will be related to the research questions and the literature discussed in Section 2 above.

\subsection{Individual factors affecting the learners' WTC in NZ and Iran (RQ1)}

In the interviews and questionnaires the key factors mentioned by the two participants as influencing their WTC in their NZ classroom were past language learning experiences, personality traits, self-confidence (as opposed to anxiety), and motivation, which are all components contributing to WTC as depicted in the MacIntyre et al. (1998) "Pyramid Model."

\subsubsection{Past language learning experiences}

The participants' lack of communicative language learning experience in Iran meant their initially low levels of communicative competence affected their classroom experiences in NZ, but they both felt that they had largely overcome this. This factor will be discussed in detail below in response to RQ2 (Section 4.2).

\subsubsection{Personality}

Shabnam made it clear that she felt her personality in the classroom did not change between Iran and NZ and that she was always extroverted and willing to speak (Quest. 1; Int. 1). Farnaz, on the other hand, stated that her personality tended towards introversion, but she did not consider that to be a negative ('I don't like more speaking, more talking I think it is not necessary' (Int. 2)). She revealed in this interview that she was similarly reluctant to speak in 
her previous L1 classes in Iran, so this reluctance may not be tied to language but to a "personality-based disposition" (MacIntyre et al., 2011: 91). MacIntyre et al. describe personality as a force over which individuals have little influence, that is a stable rather than situational trait.

Data from questionnaires completed by the teachers of the two participants and the researcher's classroom observations supported the learners' self-judgments of their personality types. Both of Farnaz's teachers described her as 'quiet, focussed and thoughtful' (Teacher Int. $1 \&$ 2) as she did herself - 'quiet' and 'relaxed', not 'talkative' (Int. 1). In the notes from the classroom observation session it was noted by the researcher that Farnaz did in fact almost exclusively communicate with just one adjacent classmate throughout the whole lesson and participated only in a unison response to the teacher's whole class questions.

Shabnam, however, was described by her Advanced and Academic English 2 teachers as always willing to communicate and they saw her as a 'very outgoing person' who was 'confident and forthcoming'(Teacher Int. $1 \& 2$ ). The classroom observation supported this view as she was constantly interacting with other learners in groups or pairs and also asking questions of the teacher. Therefore, both women's self-perceptions were very similar to the observations of their teachers and the researcher/observer.

Although the topic of personality attributes in relation to communication processes has been the subject of research for some considerable time, according to MacIntyre et al. (2007) empirical evidence is still lacking as to whether extroversion has advantages over introversion in the area of language learning. Nevertheless, they believe that even if extroversion may not be favourably linked to written abilities in the L2, it could help with the achievement of oral fluency. In the case of the two participants discussed in this article, the question is still open as to whether Farnaz is disadvantaged at all by her naturally reticent personality, or whether the extrovert, Shabnam, would ultimately be more "successful" at learning the L2.

\subsubsection{Anxiety and self-confidence}

Both participants were unconcerned about embarrassment or nervousness when speaking in front of other learners, or when being corrected by the teacher both in NZ and Iran. Farnaz attributed any lack of confidence in speaking both in Iran and NZ to her 'quiet' personality. They both felt generally relaxed in classroom interaction situations, although their feelings about groupwork differed. The less outgoing Farnaz preferred pairwork or communicating directly with the teacher (Int. 1), whereas Shabnam liked groupwork: 'I think in small groups I have a lot of confidence' (Int. 1). This self-report was borne out by their observed classroom behaviours.

Farnaz admitted to some anxiety and frustration "when sometimes I make mistake with grammar or I can't you know, when I can't remember the academic vocab, I use the vocabs I know and I use just simple ones, [or] I stop talking' (Int. 2). MacIntyre et al. (2009) describe 
this situation as: "Though the spirit is willing, the body of vocabulary is weak" (p. 20). In other words, there is a willingness to communicate overall, but at the moment of communicating, the learner becomes overwhelmed by opposing feelings of anxiety and low competence. Therefore, although there is no trait anxiety preceding a particular communication situation, a transitory state of anxiety may impede or prevent the communication event from taking place.

Farnaz's decision to 'stop talking' can also be described as hesitation in Kuhl's theory of Action Control (see MacIntyre \& Doucette, 2010), which can inhibit communication in the L2. However, Farnaz had some strategies to overcome such difficulties in her NZ situation: 'I use more gestures than talking'; 'when I talking with my friends or classmates I draw some pictures' (Int. 2).

The role of anxiety has been explored extensively in L2 learning (see Horwitz, 2010), and in WTC (Baker \& MacIntyre, 2000; MacIntyre, Baker, Clément, \& Donovan, 2003), also under the label communication apprehension (Layer IV of the "Pyramid Model" of MacIntyre et al., 1998). It has been suggested by these authors that whereas language anxiety is predominantly of the debilitating variety, a lack of anxiety (i.e. self-confidence) is a facilitating component of WTC.

The situation for these two learners seems to be that since they moved to NZ, Farnaz's self-confidence had increased, while Shabnam felt that due to her outgoing personality, she was equally confident about speaking English in both her Iranian and NZ classrooms.

\subsubsection{Motivation}

Both participants expressed strong desires to settle and integrate successfully into NZ society, and as refugees they had to make a very strong commitment to living in NZ permanently. Unlike EFL or SA learners who are either learning English in their own country or staying only temporarily in an English-speaking country, migrants' motivation to learn English is usually linked with their motivation to settle, particularly in NZ where the population is small and migrant groups cannot rely on living within large communities of people who speak their language (cf. the Chinese migrants in Zhong's 2013 study).

When asked how important it was to learn English, Farnaz said: 'It's very important because it helps me, I improve my life in New Zealand and find good job or connect with people different multicultural people, it is very important' (Int. 1). It was also 'very important because of my future, my planning, to further study' (Int. 2).

Shabnam had similar goals: 'It's very important for me because I need to improve my English to get my perfect job because I have a lot of experience in my country in teaching everything, so when I can speak English I can use this experience' (Int. 1). She also linked her level of motivation with a lack of anxiety and her preference for NZ teaching methods: 'My motivation is too high, ... here, because, I don't know, I feel so free and so comfortable and I think the rule for teaching is very good, is good and I can learn very fast' (Int. 1). 
Although these two women's initial motivation for coming to NZ might have been extrinsic, as they were seeking a place of refuge, according to MacIntyre et al. (2011) in their study of WTC, "a once-extrinsic motivator can become integrated with the individual's sense of self and purpose" and "the ongoing transition between extrinsic and intrinsic motives often makes the distinction very blurry in practice" (p. 85).

From a dynamic systems perspective, settlement in NZ for these learners had become a preferred or attractor state, but was also idiodynamically affected by a "focus on events" (MacIntyre \& Legatto, 2011: 151). In fact, the participants stressed that their ability to study effectively was hampered at times by their own personal and family situations. For example, Fariba mentioned homesickness (Int. 2), and Shabnam suggested her son's visit from Iran (Int. 2) as being factors affecting their classroom behaviour. Thus, as suggested by MacIntyre et al. (2011), "L2 acquisition and communication is rife with personal, familial, and social conflicts" (p. 93).

\subsection{The learners' WTC in NZ ESL classrooms in comparison to their WTC in EFL classrooms in Iran (RQ2)}

In order to understand the effects of a change in learning context on the WTC of the two women in this study, it is important to understand how they perceived their experiences in both pedagogical environments.

Despite the fact that Shabnam's English language learning took place 20 years prior to Farnaz's, they painted a similar picture of the Iranian EFL teaching environment. Shabnam had had some English at high school but:

It's not enough because rule is different, sometimes it's too tough, teacher is too tough, grammar, a lot of grammar everything, and that's why all the students getting bored and sometimes they are scared, they scared just forget the marks, something like that. (Int. 1)

Her experiences in a private language institute were more amenable to WTC:

No, no, it was good, it was good but at this school is different, at this school you can be volunteer, you can talk too much, if you say something wrong, or thoroughly it is embarrassing [at high school], but at the institute it is different. (Int. 1)

When describing her more recent English learning experiences in Iran, Farnaz revealed that there was still a strong emphasis on grammar with no opportunity for conversation or listening practice: 'At secondary school and tertiary we used to study, yeh, but it was more grammatical. We had no conversation, nothing, even we had nothing about listening, language lab, this is my first time' (Int. 1). Group work was not a part of language learning in Iran. There were, therefore, few opportunities for learners to show their WTC. Unlike in Shabnam's time, according to Farnaz, private institutes were now common, not too expensive 
and popular for all ages: 'especially all parents put their children in when they are really young' (Int. 1).

Such descriptions of the English language teaching situation in Iran are borne out by Iranian researchers such as Vaezi (2008), who suggests that Iranian students and teachers are disadvantaged by "a lack of resources and little contact with the target language" (p. 54), in spite of the students' high levels of motivation. In his study, Papi (2010) noted the negative association of L2 anxiety with the variable of WTC, and his conclusion was that, because "the motivation of Iranian learners of English seems to be dependent on their attitudes toward English learning," "providing a positive and motivating classroom by teachers and educational authorities seems to be an urgent necessity" (p. 476). Commenting on Iranian school syllabi, Maleki (2007) suggested that the incorporation of communication strategies in English language teaching was still controversial, but the results of his study showed that teaching such strategies was pedagogically effective.

The other learning context for this study was the NZ university English language classroom. According to Ker et al. (2013), language teaching in NZ continues to be strongly influenced by communicative language teaching methodology. Overseas textbooks and materials may be used but these are often combined with original and New Zealand-relevant sources. This was certainly the case in the classes attended by the participants in this study.

Therefore, as can be seen from the previous discussion of Iranian English language teaching practices, the Iranian learners' learning experiences in their NZ classroom may have differed markedly from their previous study environment. The medium of teaching was English, their fellow learners were from many different countries and could not speak Farsi, a strong emphasis was placed on spoken English as the primary means of communication, and materials for teaching were based less on standardised textbooks than on appropriate worksheets selected by their teachers.

In terms of overall variation in WTC between Iran and NZ, Farnaz, described herself as being more willing to speak English now because 'in NZ I feel more confidence and have more motivation to learn English' (Quest. 1). MacIntyre et al. (2011) emphasise the role that self-confidence plays in WTC, as do Alemi et al. (2011) and Ghonsooly et al. (2012) in regard to the Iranian context. In contrast, Farnaz described her English learning experiences in her Iranian high school as motivating, but that she lacked confidence in speaking (Int. 1).

Shabnam also described herself as more willing to speak in NZ:

Because a lot of student came from around the world and all of them have their own language and there is just one way to contact together and it is just speak English so here I'm more willing to speak English and I know all of them are like me so I don't shy to talk. (Quest. 1)

This lends support to MacIntyre et al.'s (2011: 90) proposal that besides selfconfidence, "the desire to speak to a person for authentic communication" is the other major 
antecedent for L2 communication. Although Shabnam said she always enjoyed English in Iran and her motivation was good, the teaching methods and institute regulations made her 'nervous.'

\subsection{Changes in the learners' WTC from one semester to another in two consecutive NZ English classes (RQ3)}

When asked about any changes in WTC from one semester in a NZ English language learning classroom to another, Farnaz described her motivation in this way:

Actually, when I just started in Advanced course, my motivation wasn't very high, because I didn't know I want to stay in New Zealand a long time, I was homesick, but little by little after I finished Advanced I got better, our plan about future fixed. (Int. 2)

Thus her preoccupation with external factors which were possibly beyond her control affected her motivation (see Kuhl, 1994). Consequently, she was unable to focus on the task, which, according to MacIntyre and Doucette (2010), is likely to lead to lower WTC both in and out of the classroom.

In the Academic English 2 class the following semester Farnaz's motivation was: 'Mmm, better than the first, I more confident, more planning, it was very important for me to get a better grade'. Her personality was now 'a little bit changed' because 'it [had] been quiet' in the previous class. She no longer felt that most of the other students spoke better English than her, and as a result of her increase in confidence she said she practised her English more outside the classroom (Int. 2). The importance of self-confidence as a precursor for WTC at both trait and state level has been recognized by WTC researchers since MacIntyre et al.'s (1998) model was conceived.

Therefore, cognitive and emotional processes converged within Farnaz over the two semesters to affect her learning in such a way that at times she was unwilling to communicate, and at others she had a high level of WTC. Such fluctuations in WTC have been described by MacIntyre et al. (2011: 81) as "ambivalence."

Shabnam, on the other hand, described her first class (Advanced) as useful for her but she had sometimes been 'confused', and now in her Academic English 2 class she was 'much much better [at comprehending], so [she could] have a bit of communication.' As to what made the difference she said: 'Maybe just me because my English a little bit improved, before I couldn't explain sometimes so I couldn't keep in touch with somebody, now I am much much better' (Int. 2). Thus she also felt the need for greater self confidence in order to take part in authentic communication.

Shabnam, like Farnaz, also mentioned external factors which she felt had adversely affected her classroom performance such as caring for her university age daughter, doing everything by herself as a single parent, and the arrival of her son: 
He was here four months and then he went back to Iran so I was upset, sometimes sad. I had too much things I had to fix because the other side my daughter is here so I have to think about her. (Int. 2)

Data from the WTC questionnaires completed by the participants at the end of each semester provided further support for their self-evaluations. Farnaz, starting from a lower baseline WTC than Shabnam, showed a slight increase in WTC from one semester to another, whereas Shabnam's initially high estimate of her WTC in the first semester was lower in some aspects in the second semester (Quest. 1 \& 2). In the interviews with their teachers it is interesting to note that they also commented on the external factors which they believed were affecting the students, although they felt Shabnam was consistently more willing to contribute to classroom speaking activities than Farnaz (Teacher Int. 1 \& 2). In-class observations by the researcher over the period of the two semesters led to a similar impression of the students' WTC as their teachers (Obs. 1-4).

To sum up, in response to RQ1, which investigated the factors considered by the students as having an important influence on their WTC, past language learning experiences, personality, anxiety, self-confidence, and motivation were all themes which recurred. As for the two changes in context explored in RQ2 and RQ3, the difference between learning English in Iran and in NZ led to a change in the students' situational WTC, due to the contrast in teaching methods and classroom environment, whereas the changes in WTC between one semester and another in NZ were due more to a developing confidence in the language. However, both students also talked about external factors in their personal and family lives which had an effect on their classroom attendance and behaviour, and also their strong commitment to their new life in NZ.

\section{CONCLUSION}

The aim of this article was to present the findings of an in-depth qualitative investigation into the WTC of two Iranian migrants to NZ. Factors which they considered to be important for their personal willingness or unwillingness to communicate have been identified. These were their past learning experiences, personality traits, self-confidence and lack of anxiety, and motivation. External events, however, which were taking place in their new lives in NZ were also considered to be significant by the participants. These are the "personal, social, and situational experiences that drive or inhibit WTC," as referred to by MacIntyre et al. (2011: $85)$.

In particular, the way in which the context of their English language learning affected their WTC in both their Iranian and NZ classrooms has been examined. In contrast to the difficulties they had experienced while learning English in Iran, and in response to the greater 
opportunities for authentic communication in NZ, they felt that their self confidence in speaking English had increased. They were less affected by the change in context between one NZ class and the next, but rather by migrant settlement issues which they experienced in that period of time.

"Context" as a factor in WTC has previously been discussed in the literature but no other studies yet published have compared the WTC of students in their own country's L2 classroom context with that of their new country of migration. Such a dramatic change in the students' environment with its attendant stresses must be worthy of further investigation.

The factor mentioned by the participants as being influential on their present WTC, i.e. past learning experiences, needs further examination. The significance of personality traits, self-confidence, lack of anxiety, and motivation has been explored in detail in previous WTC studies, but not in the migrant situation. The debate as to whether aspects of WTC have a trait or situational disposition is likely to continue, but in this study the learners felt that their personality was a constant while the other factors mentioned above varied according to context.

As can be seen in recent publications incorporating psychological theories such as Dynamic Systems and Action Control in an analysis of WTC studies, this area of language learning research is continuing to evolve and aspects of both of these theories seem applicable to the participants in this study. As suggested by MacIntyre and Blackie (2012: 541) "[i]t is important to gain an understanding of the language learner as a person, with multiple competing (sometimes conflicting) motives and priorities, using the many conceptual tools we have at hand." To do this effectively, the context of their learning experience needs to be explored, whether it is the classroom context as in this study or the wider context of the society to which they have migrated.

According to MacIntyre and Doucette (2010), "WTC is a necessary part of becoming fluent in a second language, which is the ultimate goal of many L2 learners" (p. 169). It is certainly likely to be an important goal for migrants to a new country. Therefore, the more their English language teachers understand the nature of their WTC, and the factors that have influenced this characteristic, the more they can assist their students to become communicatively competent. If the styles of teaching and classroom interaction patterns are significantly different from those which they have experienced in their country of origin, they will need to go through a period of adjustment, which in itself may be a cause of language anxiety. Minimising this anxiety will enhance their "state of readiness" to communicate in English. Classroom discussions about previous language learning experiences, one-to-one interviews with the teacher, or focus groups established to discuss such topics could be beneficial.

Although this study added a longitudinal dimension, combined with observations and teacher input, to a previous exploratory study (Cameron, 2013), the sample size was small and generalizability to other contexts is a problem. However, this is typical of qualitative case 
study research in this area (see Cao, 2013; Peng, 2011; Zhong, 2013). The researcher is not claiming that the implications drawn from these results would be duplicated in another similar study, but if such a study were to be carried out the comparisons would be a further contribution to this area of research.

As this is a new area of investigation, there is also great scope for research into factors which influence the WTC of migrants in other English-speaking areas of the world. Other groups from the many countries which provide sources of migration for NZ could also be surveyed. In this way, the influence of cultural identity on WTC could also be explored. In terms of methodology a larger sample group could be used, focus groups employed to provide a greater "voice" for the participants, and the longitudinal aspect extended.

\section{ACKNOWLEDGMENTS}

I would like to acknowledge the students of the School of Language and Culture for their help in carrying out this research, and my colleagues, in particular Helen Cartner, Gloria Vazquez, and Dr John Bitchener for their support and encouragement, and Jenny Brocas for her faithful transcriptions of the data. The comments and suggestions of the reviewers were also greatly appreciated.

\section{REFERENCES}

Alemi, M., Daftarifard, P. \& Pashmforoosh, R. (2011). The impact of language anxiety and language proficiency on WTC in EFL context. Cross-Cultural Communication, 7(3), 150-166. doi: 10.3968/j.ccc. 1923670020110703.152

Baker, S. \& MacIntyre, P. (2000). The role of gender and immersion in communication and second language orientations. Language Learning, 50(2), 311-341. doi: 10.1111/0023-8333.00119

de Bot, K., Lowie, W. \& Verspoor, M. (2007). A dynamic systems approach to second language acquisition. Bilingualism: Language and Cognition, 10, 7-21. doi: $10.1017 / \mathrm{S} 1366728906002732$

Cameron, D. (2013). Willingness to communicate in English as a second language as a stable trait or context-influenced variable: Case studies of Iranian migrants to New Zealand. Australian Review of Applied Linguistics, 36(2), 177-195. Retrieved from:

http://www.nla.gov.au/openpublish/index.php/aral/article/viewFile/3073/3615

Cao, Y. (2011). Investigating situational willingness to communicate within second language classrooms from an ecological perspective. System, 39(4), 468-479. doi: 10.1016/j.system.2011.10.016

Cao, Y. (2013). Exploring dynamism in willingness to communicate: A longitudinal case study. Australian Review of Applied Linguistics, 36(2), 160-176. Retrieved July 15, 2014, from http://www.nla.gov.au/openpublish/index.php/aral/article/viewFile/3072/3614

Cao, Y. \& Philp, J. (2006). Interactional context and willingness to communicate: A comparison of behaviour in whole class, group and dyadic interaction. System, 34(4), 480-493. doi: 10.1016/j.system.2006.05.002

Çetinkaya, Y. (2005). Turkish College Students' Willingness to Communicate in English as a Foreign Language (Unpublished doctoral dissertation). Ohio State University, Columbus, $\mathrm{OH}$.

Clément, R., Noels, K. A. \& MacIntyre, P. D. (2007). Three variations on the social psychology of bilinguality: Context effects in motivation, usage and identity. In A. Weatherall, B. M. Watson \& C. Gallois (Eds.), Language, Discourse and Social Psychology (pp. 51-77). Basingstoke, England: Palgrave MacMillan. 
Creswell, J.W. (2013). Qualitative Inquiry \& Research Design: Choosing among Five Approaches $\left(3^{\text {rd }}\right.$ ed.). London, England: Sage.

Dörnyei, Z. (2001). Teaching and Researching Motivation. Harlow, England: Pearson Education.

Dörnyei, Z. (2009). Individual differences: Interplay of learner characteristics and learning environment. Language Learning, 59(Suppl. 1), 230-248. doi: 10.1111/j.14679922.2009.00542.x

Dörnyei, Z. (2010). The relationship between language aptitude and language learning motivation: Individual differences from a dynamic systems perspective. In E. Macaro (Ed.), Continuum Companion to Second Language Acquisition (pp. 247-267). London, England: Continuum.

Duff, P. (2008). Case Study Research in Applied Linguistics. Mahwah, NJ: Lawrence Erlbaum.

Ghonsooly, B., Khajavy, G. H. \& Asadpour, S. F. (2012). Willingness to communicate in English among Iranian non-English major university students. Journal of Language and Social Psychology, 31(2), 197-211. doi: 10.1177/0261927X12438538

Hoepfl, M. C. (1997). Choosing qualitative research: A primer for technology education researchers. Journal of Technology Education, 9(1), 1-14. Retrieved August 3, 2012, from http://scholar.lib.vt.edu/ejournals/JTE/v9n1/hoepfl.html

Horwitz, E. (2010). Foreign and second language anxiety. Language Teaching, 43(2), 154-167. doi: $10.1017 / \mathrm{S} 026144480999036 \mathrm{x}$

Kang, S-J. (2005). Dynamic emergence of situational willingness to communicate in a second language. System, 33, 277-292. doi:10.1016/j.system.2004.10.004

Ker, A., Adams, R. \& Skyrme, G. (2013). Research in applied linguistics and language teaching and learning in New Zealand (2006-2010). Language Teaching, 46(2), 225-255. doi: $10.1017 / \mathrm{S} 0261444812000535$

Kuhl, J. (1994). A theory of action and state orientations. In J. Kuhl \& J. Beckmann (Eds.), Volition and Personality (pp. 9-46). Göttingen, Germany: Hogrefe \& Huber Publishers.

MacIntyre, P. D. (2007). Willingness to communicate in the second language: Understanding the decision to speak as a volitional process. The Modern Language Journal, 91(4), 564-576. doi: 10.1111/j.1540-4781.2007.00623.x

MacIntyre, P. D., Baker, S., Clément, R. \& Donovan, L. (2003). Talking in order to learn: Willingness to communicate and intensive language programs. The Canadian Modern Language Review, 59(4), 589-607. doi: 10.3138/cmlr.59.4.589

MacIntyre, P. D. \& Blackie, R. (2012). Action control, motivated strategies, and integrated motivation as predictors of language learning affect and the intention to continue learning French. System, 40(4), 533-543. doi: 10.1016/j.system.2012.10.1014

MacIntyre, P. D., Burns, C. \& Jessome, A. (2011). Ambivalence about communicating in a second language: A qualitative study of French language immersion students' willingness to communicate. The Modern Language Journal, 95(1), 81-96. doi: 10.1111/j.15404781.2010.01141x

MacIntyre, P. D., Dörnyei, Z., Clément, R. \& Noels, K.A. (1998). Conceptualizing willingness to communicate in a L2: A situational model of L2 confidence and affiliation. The Modern Language Journal, 82(4), 545-562. doi: 10.1111/j.1540-4781.1998.tb05543.x

MacIntyre, P. D., Clément, R. \& Noels, K. A. (2007). Affective variables, attitude and personality in context. In D. Ayoun (Ed.), Handbook of French Applied Linguistics (pp. 270-298). Philadelphia, PA: John Benjamins.

MacIntyre, P. D. \& Doucette, J. (2010). Willingness to communicate and action control, System, 38, 161-171. doi: 10.1016/j.system.2009.12.013

MacIntyre, P. D. \& Legatto, J. J. (2011). A dynamic system approach to willingness to communicate: Developing an idiodynamic method to capture rapidly changing affect. Applied Linguistics, 32(2), 149-171. doi: 10.1093/applin/amq037

MacIntyre, P. D., Mackinnon, S. P. \& Clément, R. (2009). Embracing affective ambivalence: A research agenda for understanding the interdependent processes of language anxiety and motivation. In P. Cheng \& J. X. Yan (Eds.), Cultural Identity and Language Anxiety (pp. 3-34). Guilin, China: Guangxi Normal University Press.

MacIntyre, P. D. \& Noels, K. (1994). Retrospective review article: The good language learner. System, 22(2), 269-280. 
McCroskey, J.C. (1997). Willingness to communicate, communication apprehension, and selfperceived communication competence: Conceptualizations and perspectives. In J. Daly, J. McCroskey, J. Ayres, T. Hopf \& D. Ayres (Eds.), Avoiding Communication: Shyness, Reticence, and Communication Apprehension (pp. 75-108). Cresskill, NJ: Hampton Press.

Maleki, A. (2007). Teachability of communication strategies: An Iranian experience. System, 35, 583594. doi: 10.1016/j.system.2007.04.001

Papi, M. (2010). The L2 motivational self system, L2 anxiety, and motivated behavior: A structural equation modeling approach. System, 38(3), 467-479. doi: 10.1016/j.system.2010.06.011

Patton, M.Q. (1990). Qualitative Evaluation Methods ( $2^{\text {nd }}$ ed.). Thousand Oaks, CA: Sage.

Peng, J-E. (2007). Willingness to communicate in the Chinese EFL classroom: A cultural perspective. In J. Liu (Ed.), English Language Teaching in China: New Approaches, Perspectives and Standards (pp.250-269). London, England: Continuum.

Peng, J-E. (2011). Changes in language learning beliefs during a transition to tertiary study: The mediation of classroom affordances. System, 39, 314-324. doi: 10.1016/j.system.2011.07.004

Peng, J-E. (2012). Towards an ecological understanding of willingness to communicate in EFL classrooms in China. System, 40(2), 203-213. doi: 10.1016/j.system.2012.02.002

Peng, J-E. \& Woodrow, L. (2010). Willingness to communicate in English: A model in Chinese EFL classroom context. Language Learning, 834-876. doi: 10.1111/j.1467-9922.2010.00576.x

de Saint Léger, D. \& Storch, N. (2009). Learners' perceptions and attitudes: Implications for willingness to communicate in an L2 classroom. System, 37(2), 269-285. doi: 10.1016/j.system.2009.01.001

Ushioda, E. (2009). A person-in-context relational view of emergent motivation, self and identity. In Z. Dörnyei \& E. Ushioda (Eds.), Motivation, Language Identity and the L2 Self (pp. 215-228). Bristol, England: Multilingual Matters.

Ushioda, E. (2014). Context and complex dynamic systems theory. In Z. Dornyei, P. D. MacIntyre \& A. Henry (Eds.), Motivational Dynamics in Language Learning (pp. 47-54). Bristol, England: Multilingual Matters.

Vaezi, Z. (2008). Language learning motivation among Iranian undergraduate students. World Applied Science Journal, 5, 54-61. Retrieved June 17, 2010, from http://www.idosi.org/wasj/wasj5(1)/9.pdf

Yashima, T. (2002). Willingness to communicate in a second language: The Japanese EFL context. The Modern Language Journal, 86(1), 54-67. doi: 10.1111/1540-4781.00136

Yashima, T. (2012). Willingness to communicate: Momentary volition that results in L2 behaviour. In S. Mercer, S. Ryan \& M. Williams (Eds.), Psychology for language learning (pp. 119-135). New York, NY: Palgrave MacMillan.

Yashima, T. \& Zenuk-Nishide, L. (2008). The impact of learning contexts on proficiency, attitudes, and L2 communication: Creating an imagined international community. System, 36(4), 566585. doi:10.1016/j.system.2008.03.006

Yin, R. K. (2003). Case Study Research. London, England: Sage Publications.

Zarrinabadi, N. (2014). Communicating in a second language: Investigating the effect of teacher on learners' willingness to communicate. System, 42, 288-295. doi: 10.1016/j.system.2013.12.014

Zhong, Q. (2013). Understanding Chinese learners' willingness to communicate in a New Zealand ESL classroom: A multiple case study drawing on the theory of planned behaviour. System, 41(3), 740-751. doi:10.1016/j.system.2013.08.001 